\title{
PARAMETRIC AND NON-PARAMETRIC STATISTICAL METHODS IN THE ASSESSMENT OF THE EFFECT OF PROPERTY ATTRIBUTES ON PRICES
}

\author{
Radosław Gaca PhD \\ Independent scientist and researcher \\ e-mail: radoslaw.gaca@gmail.com
}

\begin{abstract}
One of the basic problems in the comparison-based property valuation process is to determine the influence of property attributes on their price differential. Due to the qualitative character of the majority of property attributes as well as to the distributions of both prices and attributes, their effect on the price differential is increasingly often assessed by means of non-parametric statistical methods. As a tool for determining the effect of attributes on prices, many authors propose parametric methods, in particular multiple regression models. The study presents a comparison of the results of property market attribute weight estimation obtained by means of the Spearman rank correlation coefficient with the ceteris paribus adjustment and the multiple regression model based on a set of transactions with built-up land property. In both of the analyzed methods, qualitative variables were modeled with the use of the Osgood semantic differential scale. The results of the analysis show the equivalence of the applied methods. Property attribute weights calculated using the method based on the rank correlation coefficient with the ceteris paribus adjustment and the multiple regression model, both with the same level of relevance, showed almost identical values. This indicates that both parametric and non-parametric methods can be used to estimate weights.
\end{abstract}

Key words: property attribute weights, property valuation, parametric and non-parametric methods.

JEL Classification: C49, C50, R39.

Citation: Gaca R., 2018, Parametric and Non-Parametric Statistical Methods in the Assessment of the Effect of Property Attributes on Prices, Real Estate Management and Valuation, vol. 26, no. 2, pp. 83-91.

DOI: $10.2478 /$ remav-2018-0018

\section{Introduction}

One of the fundamental issues in the process of comparative property valuation is to define the effect of property attributes on their price differential. Together with the income-based and the mixed approach, the comparative approach is one of the methods of determining the property market value. It was defined in the Property Management Act of 21 August 1997 and in the Ordinance of the Council of Ministers of 21 September 2004 on property valuation and the development of the Valuation Report. In accordance with § 4.2. of the Ordinance "the comparative approach uses the method of comparison in pairs, the method of adjustment to the average price or the statistical market analysis method". The above methods are based on adjusting the attributes of the valued property in relation to the reference property.

Due to the qualitative character of the majority of property attributes as well as taking account of the distributions of both the prices and the attributes, their effect on the price differential is increasingly often determined by means of non-parametric statistical methods (GACA, SAWIŁOW 2014a; 
KULCZYCKI, LIGAS 2014; BARAŃSKA 2012). Generally, the parametric methods, particularly in the form of the multi regression model, are proposed by many authors merely as direct instruments of market property valuation, and not as methods supporting the comparative analysis of the influence of the property attribute differential on property prices (FORYŚ 2011; HOZER 2001; LIGAS 2011; DOSZYŃ 2012).

The purpose of this paper is to compare the results of property market attribute weight estimation by means of the Spearman rank correlation coefficient with the ceteris paribus adjustment and multiple regression model.

\section{Market Data}

The study is based on transactions with built-up land property concluded from January 2013 to July 2015 in two neighboring gminas (elementary units of local government) near Bydgoszcz. The calculations were made basing on a set of properties that were similar within the meaning of Article 4 item 16 of the Property Management Act. According to its provisions, a property is similar when it is comparable with another valuated property in terms of its location, legal status, designation, utility and other attributes affecting its value. The set of land properties met the criteria of a set of similar properties in a narrow approach, according to which the property being compared has parameters (attributes) of values similar to the property being valuated (GACA 2016).

In the case of the analyzed set, the author performed a linear adjustment of transaction prices because of the observed changes in prices over the period of analysis at the level of $-4 \%$ annually. The adopted range of price changes was determined based on a study carried out on a wider sample of built-up land properties in the observed area. The index of price changes resulting from the time effect and the adjusted transaction prices are shown in Table 1.

Set of similar properties selected for the study

\begin{tabular}{|c|c|c|c|c|c|c|c|}
\hline Object & $\begin{array}{c}\text { Transaction } \\
\text { date }\end{array}$ & $\begin{array}{l}\text { Building } \\
\text { size }\left(\mathrm{m}^{2}\right)\end{array}$ & $\begin{array}{l}\text { Plot } \\
\text { size } \\
\left(\mathrm{m}^{2}\right)\end{array}$ & $\begin{array}{c}\text { Transacti } \\
\text { on price } \\
(\mathrm{PLN})\end{array}$ & $\begin{array}{c}\text { Transaction } \\
\text { price per } \\
\text { unit } \\
\left(\mathrm{PLN} / \mathrm{m}^{2}\right)\end{array}$ & $\begin{array}{l}\text { Change in } \\
\text { prices over } \\
\text { time }\end{array}$ & $\begin{array}{c}\text { Transaction } \\
\text { price updated } \\
\text { in Sep. } 2015 \\
\left(\mathrm{PLN} / \mathrm{m}^{2}\right)\end{array}$ \\
\hline 1 & 2015-07-31 & 120.00 & 906 & 420000 & 3500 & 0.993 & 3477 \\
\hline 2 & 2015-07-17 & 186.34 & 1114 & 650000 & 3488 & 0.993 & 3465 \\
\hline 3 & 2015-07-07 & 150.00 & 1070 & 470000 & 3133 & 0.993 & 3112 \\
\hline 4 & 2015-06-11 & 114.85 & 1461 & 415000 & 3613 & 0.990 & 3577 \\
\hline 5 & 2015-05-31 & 190.40 & 844 & 690000 & 3624 & 0.987 & 3576 \\
\hline 6 & 2015-05-18 & 118.00 & 1000 & 490000 & 4153 & 0.987 & 4097 \\
\hline 7 & 2015-04-01 & 220.00 & 1003 & 850000 & 3864 & 0.983 & 3799 \\
\hline 8 & 2015-03-06 & 190.00 & 1003 & 500000 & 2632 & 0.980 & 2579 \\
\hline 9 & 2015-02-12 & 120.00 & 1205 & 315000 & 2625 & 0.977 & 2564 \\
\hline 10 & 2014-11-24 & 170.00 & 1044 & 415000 & 2441 & 0.967 & 2360 \\
\hline 11 & 2014-11-07 & 215.00 & 1342 & 500000 & 2326 & 0.967 & 2248 \\
\hline 12 & 2014-09-04 & 118.10 & 902 & 360000 & 3048 & 0.960 & 2926 \\
\hline 13 & 2014-08-01 & 135.00 & 854 & 450000 & 3333 & 0.957 & 3189 \\
\hline 14 & 2014-07-30 & 109.60 & 1267 & 430000 & 3923 & 0.953 & 3740 \\
\hline 15 & 2014-06-09 & 210.00 & 1048 & 435000 & 2071 & 0.950 & 1968 \\
\hline 16 & 2014-05-19 & 157.90 & 1552 & 440000 & 2787 & 0.947 & 2638 \\
\hline 17 & 2014-05-12 & 144.08 & 1118 & 348000 & 2415 & 0.947 & 2287 \\
\hline 18 & 2014-04-23 & 131.70 & 1398 & 430000 & 3265 & 0.943 & 3080 \\
\hline 19 & 2014-04-14 & 104.00 & 894 & 410000 & 3942 & 0.943 & 3719 \\
\hline 20 & 2014-03-26 & 153.00 & 1447 & 480000 & 3137 & 0.940 & 2949 \\
\hline 21 & 2014-03-07 & 156.50 & 1105 & 340000 & 2173 & 0.940 & 2042 \\
\hline 22 & 2014-03-07 & 159.50 & 1518 & 500000 & 3135 & 0.940 & 2947 \\
\hline 23 & 2014-02-28 & 144.10 & 1364 & 550000 & 3817 & 0.937 & 3575 \\
\hline 24 & 2014-02-14 & 190.00 & 1145 & 580000 & 3053 & 0.937 & 2859 \\
\hline
\end{tabular}




\begin{tabular}{cccccccc}
\hline 25 & $2014-01-31$ & 179.00 & 1617 & 550000 & 3073 & 0.933 & 2868 \\
\hline 26 & $2014-01-21$ & 170.00 & 1029 & 600000 & 3529 & 0.933 & 3294 \\
\hline 27 & $2014-01-20$ & 132.00 & 748 & 420000 & 3182 & 0.933 & 2970 \\
\hline 28 & $2013-11-27$ & 149.20 & 1345 & 350000 & 2346 & 0.927 & 2174 \\
\hline 29 & $2013-11-07$ & 233.00 & 978 & 540000 & 2318 & 0.927 & 2148 \\
\hline 30 & $2013-10-25$ & 149.00 & 683 & 480000 & 3221 & 0.923 & 2974 \\
\hline 31 & $2013-06-24$ & 180.70 & 980 & 435000 & 2407 & 0.910 & 2191 \\
\hline 32 & $2013-06-14$ & 184.70 & 731 & 587000 & 3178 & 0.910 & 2892 \\
\hline 33 & $2013-06-10$ & 143.00 & 782 & 490000 & 3427 & 0.910 & 3118 \\
\hline 34 & $2013-04-24$ & 98.40 & 716 & 390000 & 3963 & 0.903 & 3580 \\
\hline 35 & $2013-03-04$ & 170.00 & 1026 & 410000 & 2412 & 0.900 & 2171 \\
\hline 36 & $2013-01-21$ & 151.00 & 840 & 550000 & 3642 & 0.893 & 3254 \\
\hline
\end{tabular}

Source: own study.

The transactions selected for the study constituted a set of objects at a homogeneous attribute rate, as listed in the aforementioned definition of a similar property (location, legal status, designation and utility), at the same time differing in terms of individual qualities and size parameters. Therefore, the above set can be considered as a basis for determining the market value of a property by means of the comparative approach, both with the use of comparison in pairs and average price adjustment.

For the thus defined set, the author verified a null hypothesis that time-adjusted transaction prices satisfied the conditions of normal distribution. In the Shapiro-Wilk test, the test statistic value was $\mathrm{W}=0.95889$ and $\mathrm{p}=0.1986$. The test results do not justify the rejection of the null hypothesis at $\alpha=0.05$; however, it is worth noting that this takes place when the level of $p$ is relatively low.

The attributes differentiating the analyzed set in the qualitative and physical sense include:

- location (X1),

- technical condition of a building (X2),

- land development (X3),

- plot size $(X 4)$,

- building size (X5).

The selected property attributes (X1 - X3) were analyzed and modeled by means of a semantic differential. The semantic differential was proposed by Osgood in 1952. (OsGOOD 1952). The semantic differential (SD) is a type of a rating scale measuring the potency of attributes of a given object or event through defining its connotative meaning for the respondent. SD belongs to multi-dimensional scaling methods (BIELA 1992) used for examining the meaning of specific notions or the perception of objects (people, events, objects, expressions or phenomena) in the semantic domain. In 2015-2016, studies on the application of SD in the evaluation of property attributes were conducted by FORYS and GACA (FORYŚ, GACA 2015).

In the study, the semantic domain was determined by pairs of adjectives adequately describing a given attribute.

The attribute of location was described by ten scales: attractive - unattractive; suburban - central; convenient - inconvenient; quiet - noisy; easily accessible via public transportation - inaccessible via public transportation; known - unknown; beautiful - ugly; picturesque - dull; swampy - dry; urbanized - non-urbanized.

The attribute of technical-condition was described by eleven scales: well-maintained - neglected; dry - damp; free of cracks - cracked; dilapidated - renovated; old - new; mold-infested - mold-free; wornout - no wear; modern - outdated; faulty - faultless;

For the description of land development, nine scales were used: outdated - modern, orderly disorderly, well-maintained - poorly maintained, fenced - unfenced, paved - unpaved, tasteful tasteless, chaotic - organized, attractive - unattractive, green - no greenery.

The above outlined semantic domain referring to a valuating dimension enabled the author to measure the values of individual attributes at the following levels:

X1 1 - medium, 2 - good, 3 - very good;

X2 1 - good, $2-\operatorname{good}(+), 3$ - very good; 
X3 1 - good, $2-\operatorname{good}(+), 3-$ very good.

The attributes of semi-qualitative character related to size parameters (X4 and X5) were converted into qualitative variables by discriminating the set into subsets of equal total size of 20 percentiles. The rating scale of 1-5 was adopted providing that the bigger the building size (destimulant), the lower the quality of the building size attribute (X4) while the quality of the land size attribute (X5) went up as the surface area of the plot (stimulant) got bigger.

Finally, the attribute values quantified with the use of the aforementioned methods as well as the transaction prices of similar properties in the set adjusted by the time effect were written in a matrix X:

$$
X=\left[\begin{array}{cccc}
x_{11} & \ldots & x_{1 m} & c_{1} \\
x_{21} & \ldots & x_{2 m} & c_{2} \\
\ldots & \ldots & \ldots & \ldots \\
x_{n 1} & \ldots & x_{n m} & c_{n}
\end{array}\right]
$$

where:

$x_{i j} \quad$ - the value of the $j$-th attribute for the $i$-th property, where $i=1,2, \ldots, \mathrm{n}, j=1,2, \ldots, \mathrm{m}$

$c_{i} \quad$ - the price of the $i$-th property adjusted by time effect, where: $i=1,2, \ldots, \mathrm{n}$.

Information in matrix $X$ is base-line data to determine the property value in a comparative approach, including the identification of the individual attributes' effect on price differentiation.

Relatively small differentiation of the assessed qualitative attributes as well as the use of a threepoint rating scale results from the high-degree of homogeneity of the set of similar properties consisting solely of land properties built up with new residential buildings. The described situation is a typical one when we determine property market values on relatively well-developed markets and results explicitly from the aforementioned and regulated by law rules of property valuation.

\section{Non-Parametric Method of Determining the Effect of Property Attributes on Price Differentiation}

In order to assess the effect of "differences in individual property prices" on price differentiation within the observed group of similar properties, the author applied a method based on Spearman rank correlation analysis (GACA, SAWIŁOW 2014a). The correlation coefficients for individual attributes were computed having regard to the ceteris paribus principle. The adjusted prices were calculated according to Formula 3 as a ratio of the total rating of the $i$-th property's attributes excluding the attribute under analysis to the respective total of the medians from the rating scale. The above procedure led to eliminating a considerable part of the effect of attributes on transaction prices different from the one for which the correlation coefficient is calculated. Therefore, the applied procedure made the adjusted prices approach the level which they would reach if all their attributes besides the examined one were ranked identically (ceteris paribus) (GACA, SAWIEOW 2014b). The price adjustments to the ceteris paribus status, i.e. the calculations of the adjusted prices, were made according to the formula

$$
C s_{i j}=C_{i}-\Delta C \cdot\left(1-W k_{i j}\right)
$$

where:

$C_{i j} \quad$ - the adjusted unit price of the $i$-th property due to the $j$-th attribute,

$C_{i} \quad$ - the price of the $i$-th property adjusted by the time effect,

$\Delta C$ - the difference between the maximum and minimum unit price adjusted by the time effect,

$W k_{i j} \quad$ - the coefficient that adjusts the unit price of the $i$-th property due to the $j$-th attribute to the ceteris paribus status, in relation to the statuses of the remaining attributes, determined according to the formula

$$
W k_{i j}=\frac{\sum_{l \neq j} M e}{\sum_{l \neq j} x_{i l}}
$$

where:

$M e_{l} \quad$ - the rating scale median of the $l$-th attribute, where: $l=1,2, \ldots, \mathrm{m}$ 
$x_{i l} \quad$ - the value of the $l$-th attribute for the $i$-th property.

Basing on the above calculations, Matrix $\mathbf{Y}$ of the adjusted prices $C_{S i j}$ was obtained

$$
\mathrm{Y}=\left[\begin{array}{cccc}
\mathrm{Cs}_{11} & \ldots & \mathrm{Cs}_{1 \mathrm{~m}-1} & \mathrm{Cs}_{1 \mathrm{~m}} \\
\mathrm{Cs}_{21} & \ldots & \mathrm{Cs}_{2 \mathrm{~m}-1} & \mathrm{Cs}_{2 \mathrm{~m}} \\
\ldots & \ldots & \ldots & \ldots \\
\mathrm{Cs}_{\mathrm{n} 1} & \ldots & \mathrm{Cs}_{\mathrm{nm}-1} & \mathrm{Cs}_{\mathrm{nm}}
\end{array}\right]
$$

The adjusted prices in the matrix included the effect of all the analyzed attributes on the price level and differentiation by taking into account their relation to the central value (a median from the rating scale for individual attributes). This means that, when the correlation coefficients were computed for each attribute, the effect of the differentiation observed in reference with the remaining attributes was generally eliminated.

In the next step, for the sake of the applied non-parametric method, the Spearman rank correlation was computed between the individual attributes and prices adjusted to the ceteris paribus state. The calculation of rank correlation was made using the formula

$$
\rho_{j}=1-\frac{6 \cdot \sum_{i=1}^{n} d_{i j}^{2}}{n \cdot\left(n^{2}-1\right)}
$$

where:

$\rho_{j} \quad-$ the value of correlation rank for the $j$-th attribute,

$d_{i j}=c r_{i j}-x r_{i j},(i=1, \ldots, n ; j=1, \ldots, m)$ where $c r_{i j}$ - the rank of the adjusted prices $C s_{i j}, x r_{i j}$ - the rank of the attribute values $x_{i j}$.

Basing on the obtained statistically relevant correlations, the weights of market attributes $w g_{j}$ were calculated according to the formula

$$
w g_{j}=\frac{\left|\rho_{j}\right|}{\sum_{j=1}^{m}\left|\rho_{j}\right|}
$$

where:

$\rho_{j}>\rho^{*}(\alpha)$ where $\rho^{*}$ is the critical value of the rank correlation coefficient for a specified relevance level $\alpha$.

\section{Parametric Method of Determining the Effect of Property Attributes on Price Differentiation}

The parametric method used to achieve the research objective was based on the linear multiple regression model

$$
Y=a_{0}+a_{1} X_{1}+a_{2} X_{2}+\ldots .+a_{m} X_{m}+\varepsilon
$$

where:

$Y \quad$ - the dependent variable,

$a_{1}, a_{2}, \ldots a_{m} \quad$ - coefficients of the multiple regression equation,

$X_{1}, X_{2}, \ldots X_{m}$ - the independent variables,

$\varepsilon \quad-$ the random factor.

The model parameters were based on Matrix $X$ for the analyzed set of similar properties. The coefficients of the multiple regression equation were calculated by means of the least squares method. The weights of market prices were determined basing on the assumption that they reflected the effect of individual statistically relevant attributes on the differentiation of prices that were calculated with the use of the model for data from Matrix X. The statistical relevance for particular regression equation coefficients was evaluated in reference to the $p$-value.

The weights of market attributes were determined by means of inserting extreme independent variable values into Equation (7), thus obtaining the model values of extreme prices 


$$
\begin{aligned}
& C_{\text {min }}=a_{0}+a_{1} X_{1 \text { min }}+a_{2} X_{2 \min }+\ldots .+a_{m} X_{m \text { min }}+\varepsilon \\
& C_{\text {max }}=a_{0}+a_{1} X_{1 \text { max }}+a_{2} X_{2 \text { max }}+\ldots .+a_{m} X_{m \text { max }}+\varepsilon
\end{aligned}
$$

where:

$C_{\min }$ - the theoretical minimum price calculated with the regression equation,

$C_{\max }$ - the theoretical maximum price calculated with the regression equation,

$X_{j \text { min }} \quad$ - the minimum rank of the $j$-th attribute,

$X_{j \max } \quad$ - the maximum rank of the $j$-th attribute.

Making the difference from both sides of Equation (8) we have

$$
\Delta C=C_{\text {max }}-C_{\text {min }}=a_{1}\left(X_{1 \text { max }}-X_{1 \text { min }}\right)+a_{2}\left(X_{2 \max }-X_{2 \min }\right)+\ldots .+a_{m}\left(X_{m \text { max }}-X_{m \text { min }}\right)
$$

where:

$\Delta C \quad$ - the theoretical price differential calculated on the basis of the regression equation.

Dividing Equation (9) by $\Delta \mathrm{C}$, we receive

$$
1=a_{1}\left(X_{1 \max }-X_{1 \min }\right) / \Delta C+a_{2}\left(X_{2 \max }-X_{2 \min }\right) / \Delta C+\ldots .+a_{m}\left(X_{m \max }-X_{m \min }\right) / \Delta C
$$

On the basis of the above, the weight of the $j$-th attribute $w g_{j}$ is a ratio of the respective price differential expressed in absolute value to the theoretical price differential computed basing on the regression equation $\Delta C$. In the proposed approach, the weights of market attributes were determined according to the formula

$$
w g_{j}=\left|a_{j}\left(X_{j \max }-X_{j \min }\right)\right| / \Delta C
$$

\section{Study Results}

The purpose of this study was to compare the estimation results of the weights of property market attributes determined by means of the methods described above. With both methods, in view of the comparability of results, the author adopted an identical relevance level at $\alpha=0.05$ when verifying the null hypotheses regarding the absence of the relevance of Spearman correlation coefficients or direction coefficients in the multiple regression equation. In the parametric method, the computations were based on the attribute ranks and the transaction prices in a set of similar properties adjusted by the time effect and written in Matrix X.

In the case of the non-parametric method, before calculating the rank correlation coefficients, the

\begin{tabular}{|c|c|c|c|c|c|c|c|c|c|c|}
\hline \multirow{2}{*}{ Object } & \multicolumn{5}{|c|}{ Differentiating attributes and their rank } & \multicolumn{5}{|c|}{$\begin{array}{l}\text { Prices adjusted to ceteris paribus state } \\
\qquad\left(\mathrm{PLN} / \mathrm{m}^{2}\right)\end{array}$} \\
\hline & $\mathbf{X} 1$ & $\mathrm{X} 2$ & $\mathrm{X} 3$ & $\mathrm{X} 4$ & $\mathrm{X} 5$ & $C s_{i 1}$ & $C s_{i 2}$ & $C s_{i 3}$ & $C s_{i 4}$ & $C s_{i 5}$ \\
\hline 1 & 2 & 2 & 2 & 2 & 4 & 3477 & 3477 & 3477 & 3264 & 3743 \\
\hline 2 & 3 & 3 & 2 & 3 & 2 & 3465 & 3465 & 3271 & 3252 & 3078 \\
\hline 3 & 2 & 2 & 2 & 3 & 3 & 3112 & 3112 & 3112 & 3112 & 3112 \\
\hline 4 & 2 & 2 & 2 & 4 & 4 & 3222 & 3222 & 3222 & 3364 & 3364 \\
\hline 5 & 2 & 3 & 2 & 2 & 2 & 3812 & 4108 & 3812 & 3576 & 3576 \\
\hline 6 & 3 & 3 & 3 & 3 & 4 & 3606 & 3606 & 3606 & 3442 & 3565 \\
\hline 7 & 3 & 3 & 3 & 3 & 1 & 3799 & 3799 & 3799 & 3586 & 3267 \\
\hline 8 & 2 & 2 & 1 & 3 & 2 & 3111 & 3111 & 2816 & 3187 & 2845 \\
\hline 9 & 2 & 2 & 2 & 3 & 4 & 2370 & 2370 & 2370 & 2351 & 2564 \\
\hline 10 & 3 & 3 & 1 & 3 & 3 & 2360 & 2360 & 2005 & 2147 & 2147 \\
\hline 11 & 2 & 3 & 1 & 4 & 1 & 2485 & 2780 & 2248 & 2856 & 2035 \\
\hline 12 & 2 & 2 & 2 & 2 & 4 & 2926 & 2926 & 2926 & 2713 & 3192 \\
\hline
\end{tabular}
ceteris paribus price adjustment was made. Table 2 shows the calculation of vectors of the adjusted prices with reference to individual attributes.

Table 2

Description of differentiating attribute ranks in a set of similar properties and the adjusted prices $C s_{i j}$ 


\begin{tabular}{lllllllllll}
\hline 13 & 3 & 3 & 3 & 2 & 4 & 2834 & 2834 & 2834 & 2534 & 2802 \\
\hline 14 & 2 & 3 & 3 & 4 & 5 & 3030 & 3132 & 3132 & 3085 & 3208 \\
\hline 15 & 3 & 1 & 1 & 3 & 2 & 2880 & 2204 & 2204 & 2576 & 2234 \\
\hline 16 & 3 & 2 & 3 & 5 & 3 & 2147 & 2030 & 2147 & 2251 & 1983 \\
\hline 17 & 2 & 2 & 2 & 3 & 3 & 2287 & 2287 & 2287 & 2287 & 2287 \\
\hline 18 & 3 & 3 & 3 & 4 & 4 & 2472 & 2472 & 2472 & 2425 & 2425 \\
\hline 19 & 3 & 3 & 3 & 2 & 5 & 3228 & 3228 & 3228 & 2958 & 3332 \\
\hline 20 & 1 & 2 & 2 & 4 & 3 & 2755 & 2949 & 2949 & 3215 & 2949 \\
\hline 21 & 2 & 1 & 1 & 3 & 3 & 2575 & 2279 & 2279 & 2651 & 2651 \\
\hline 22 & 2 & 3 & 3 & 5 & 3 & 2338 & 2455 & 2455 & 2560 & 2292 \\
\hline 23 & 3 & 3 & 3 & 4 & 3 & 3084 & 3084 & 3084 & 3043 & 2920 \\
\hline 24 & 3 & 3 & 2 & 3 & 2 & 2859 & 2859 & 2666 & 2646 & 2472 \\
\hline 25 & 3 & 3 & 2 & 5 & 2 & 2513 & 2513 & 2376 & 2655 & 2213 \\
\hline 26 & 2 & 3 & 3 & 3 & 3 & 2939 & 3101 & 3101 & 2907 & 2907 \\
\hline 27 & 1 & 2 & 2 & 1 & 4 & 3206 & 3502 & 3502 & 2970 & 4034 \\
\hline 28 & 3 & 1 & 1 & 4 & 3 & 2410 & 1980 & 1980 & 2440 & 2174 \\
\hline 29 & 1 & 2 & 2 & 2 & 1 & 3060 & 3567 & 3567 & 3212 & 2756 \\
\hline 30 & 2 & 3 & 2 & 1 & 3 & 3211 & 3507 & 3211 & 2762 & 3241 \\
\hline 31 & 3 & 2 & 2 & 2 & 2 & 2723 & 2427 & 2427 & 2191 & 2191 \\
\hline 32 & 2 & 3 & 2 & 1 & 2 & 3424 & 3805 & 3424 & 2892 & 3158 \\
\hline 33 & 2 & 3 & 1 & 1 & 3 & 3651 & 4031 & 3355 & 3118 & 3727 \\
\hline 34 & 3 & 3 & 1 & 1 & 5 & 3580 & 3580 & 3225 & 3048 & 3846 \\
\hline 35 & 1 & 2 & 1 & 3 & 3 & 2407 & 2703 & 2407 & 2779 & 2779 \\
\hline 36 & 3 & 3 & 2 & 2 & 3 & 3254 & 3254 & 3060 & 2867 & 3041 \\
\hline
\end{tabular}

Source: own study.

In the following step, the Spearman rank correlation coefficients were calculated for individual attributes and their respective adjusted prices. Also, the statistical relevance of individual coefficients was determined. Then, Formula (6) was used to compute the attribute weights. The market attribute estimation results performed by means of the non-parametric method are shown in Table 3.

Table 3

Market attribute estimation results performed by means of Spearman rank correlation coefficients

\begin{tabular}{lcccc}
\hline \multicolumn{1}{c}{ Attribute } & $\begin{array}{c}\text { Spearman rank } \\
\text { correlation with } \\
\text { adjusted prices Csij }\end{array}$ & $\begin{array}{c}\text { Relevance } \\
\rho<\rho_{k r}(0.279)^{*} \\
\text { no grounds for } \\
\text { rejecting } \mathrm{H}_{0}\end{array}$ & $\begin{array}{c}\text { Actual } \\
\text { attribute } \\
\text { share } \\
(\%)\end{array}$ & $\begin{array}{c}\text { Rounded } \\
\text { attribute share } \\
(\%)\end{array}$ \\
\hline Location & 0.104 & 0.000 & 0.00 & $\mathbf{0 . 0 0}$ \\
\hline $\begin{array}{l}\text { Technical condition of a } \\
\text { building }\end{array}$ & 0.513 & 0.513 & 38.93 & $\mathbf{3 9 . 0 0}$ \\
\hline Land development & 0.366 & 0.366 & 28.24 & $\mathbf{2 8 . 0 0}$ \\
\hline Plot size & -0.147 & 0.000 & 0.00 & $\mathbf{0 . 0 0}$ \\
\hline Building size & 0.434 & 0.4340 & 32.82 & $\mathbf{3 3 . 0 0}$ \\
\hline
\end{tabular}

*) Critical value of $\rho_{k r}$ at relevance level of 0.05 , for $\mathrm{n}=36$ is 0.2790 (RAMSEY 1989).

Source: own study. 


\section{$\$$ sciendo}

With the parametric method, the values of market attribute weights were determined using Formula (11). The attribute weight estimation results obtained by means of the multiple regression model (see Point 4) are shown in Table 4.

Table 4

Market attribute weights calculated using the multiple regression model (parametric method)

\begin{tabular}{lccccc}
\hline \multicolumn{1}{c}{ Attribute } & $\begin{array}{c}\text { Direction } \\
\text { coefficient }\end{array}$ & $\begin{array}{c}\text { Relevance } \\
\mathrm{p}>\alpha(0.05) \text { no } \\
\text { grounds for } \\
\text { rejecting } \mathrm{H}_{0}\end{array}$ & $\begin{array}{c}\text { Quota } \\
\text { share of } \\
\Delta \mathrm{C}\end{array}$ & $\begin{array}{c}\text { Actual } \\
\text { attribute } \\
\text { share } \\
(\%)\end{array}$ & $\begin{array}{c}\text { Rounded } \\
\text { attribute } \\
\text { share } \\
(\%)\end{array}$ \\
\hline Location & 36.92 & 0.718 & 0.00 & 0.00 & $\mathbf{0 . 0 0}$ \\
\hline $\begin{array}{l}\text { Technical condition of } \\
\text { a building }\end{array}$ & 377.80 & 0.003 & 755.60 & 38.61 & $\mathbf{3 9 . 0 0}$ \\
\hline Land development & 273.95 & 0.017 & 547.90 & 28.00 & $\mathbf{2 8 . 0 0}$ \\
\hline Plot size & -61.23 & 0.329 & 0.00 & 0.00 & $\mathbf{0 . 0 0}$ \\
\hline Building size & 163.33 & 0.016 & 653.32 & 33.39 & $\mathbf{3 3 . 0 0}$ \\
\hline
\end{tabular}

Source: own study.

The rounded results obtained in the two models were much the same in terms of both the relevance of individual variables and their effect on price differentiation in the analyzed set of similar properties. Due to differences in the structure of the mathematical instruments used under the applied methods, their critical value levels vary, both in absolute and percentage terms.

In the author's opinion the obtained results indicate that both parametric and non-parametric methods are applicable at the stage of market analysis and when estimating the valuation model parameters. The observed comparability of the estimation results may come from both the similarity of the properties under study and the accurate definition of the differentiating attributes as well as their correct assessment.

\section{Conclusions}

As emerges from the calculations made on the given set of similar properties, in order to determine the weights of their market attributes, both of the applied methods, i.e. the parametric and the nonparametric one, led to much the same results. The weights calculated by means of the method based on rank correlation and the ceteris paribus adjustment and by means of the multiple regression model, with the same relevance level, were practically identical. The analyses revealed convergence of the statistical relevance of individual variables as well as of the weight values. Moreover, the above findings confirm the robustness of the assumptions of the ceteris paribus adjustment method, at least in relation to some sets of similar properties.

It cannot be concluded on the basis of a single example the application of parametric and nonparametric methods for different sets of similar properties will bring identical results in every situation. However, it should be noted that the above analyses show that such a scenario is possible.

In the case of discordant results, the main criterion for the choice of method can be the analysis of elementary diagnostic parameters, i.e. the coefficient of determination, the coefficient of variation or the analysis of residual distribution. In the situation when the obtained models use a different number of independent variables, we should consider the coefficients that take this into regard as appropriate. Such coefficients include both the adjusted coefficient of determination as well as other information criteria, e.g. AIC (Akaike Information Criterion) or BIC (Bayesian Information Criterion). The final choice of the model should stem from respectively better values of the above indicators. Additionally, because the inference is based on rank correlation, the non-parametric method is more resistant to outliers and more appropriate for small sets. The latter reason in particular may be of crucial importance for the applicability of the method, since the sets of similar properties are usually small.

For the purpose of fully confirming the conclusions from the above analysis it seems necessary to run further studies and calculations for other sets of real properties. As has been mentioned above, the 
presented results show that, at the stage of market analysis and estimation of valuation model parameters, both the parametric and non-parametric methods can be applied. The use of the mathematical methods described above has a significant impact on the increased objectivity of the property valuation in comparison with methods based solely on the intuitive assessment of the effect of individual property attributes on price differentiation, thus contributing to a higher quality of property valuation surveys.

\section{Reference}

BARAŃSKA A., 2012, Application of non-parametric tests of significance to the market analyses, FIG Working Week 2012

BIELA A., 1992, Skalowanie wielowymiarowe jako metoda badań naukowych (Multidimensional Scaling as a Research Method) [in Polish], (Vol. 22). Tow. Naukowe Katolickiego Uniwersytetu Lubelskiego.

DoszYŃ M., 2012, Ekonometryczna wycena nieruchomości (Econometric Property Valuation) [in Polish] Metody Ilościowe w Ekonomii. Studia i Prace Wydziału Nauk Ekonomicznych i Zarządzania (Quantitative Methods in Economy. Studies and Works of Faculty of Economic Studies and Management) No. 26, Wydawnictwo Naukowe Uniwersytetu Szczecińskiego (Scientific Publishing of Szczecin University), Szczecin, pp. 41-52.

FORYŚ I., 2011, Wykorzystanie metod taksonomicznych do wyboru obiektów podobnych w procesie wyceny lokali mieszkalnych, (The Multivariate Analysis Using to the Choice the Similar Object in the Housing Valuation Process) [in Polish] Studia i Materiały Towarzystwa Naukowego Nieruchomości (Journal of Polish Real Estate Scientific Society), 18, No. 1, Olsztyn, pp. 95-107.

FORYŚ I., GACA R., 2016, Application of the Likert and Osgood Scales to Quantify the Qualitative Features of Real Estate Properties Folia Oeconomica Stetinensia, ISSN (Online) 1898-0198, DOI: https:// doi.org/10.1515/foli-2016-0021.

GACA R., 2016, Interpretacja pojęcia "nieruchomość podobna" (Interpretation of the Term "Similar Property") [in Polish] Rzeczoznawca Majątkowy No. 89, Warszawa, pp. 16-24.

GACA R. SAWIŁOW E., 2014a, Zastosowanie wspótczynników korelacji rang Spearmana do ustalania wag cech rynkowych nieruchomości, (Application of Spearman's Rank Correlation Coefficient for Establishing Ranks of Real Estate Characteristics) [in Polish] Rzeczoznawca Majątkowy No. 82, Warszawa, pp. 24-30.

GACA R., SAWIEOW E., 2014b, Korygowanie stanów cech nieruchomości do stanu „ceteris paribus” przy ustaleniu wag cech rynkowych nieruchomości z zastosowaniem korelacji rang Spearmana, (Correcting the States of a Property's Features to the "Ceteris Paribus" State when Determining the Weight of Market Features of a Real Estate Using Spearman's Rank Correlation) [in Polish] Rzeczoznawca Majątkowy No. 82, Warszawa, pp. 48-51.

HOzER J., 2001, Regresja wieloraka a wycena nieruchomości, (Multiple Regression in Real Estate Valuation) [in Polish] Rzeczoznawca Majątkowy No. 2, Warszawa, pp. 13-14.

KUlCZYCKI M., LigAS M., 2014, Qualitative Similarity Coefficients in Real Estate Market Analysis. Geomatics and Environmental Engineering, 8.

LIGAS M., 2011, Metody statystyczne w wycenie nieruchomości (Statistical Methods in Property Valuation) [in Polish] Studia i Materiały Towarzystwa Naukowego Nieruchomości (Studies and Materials of the Polish Real Estate Scientific Society), 18, No. 1, Olsztyn, pp. 49-65.

OsGood C. E., 1952, The Nature and Measurement of Meaning. Psychological bulletin, 49(3), 197.

RAMSEY P.H., 1989, Critical Values for Spearman's Rank Order Correlation, Journal of Educational Statistics, Vol. 14, No. 3, pp. 245-253.

Rozporządzenie Rady Ministrów z dnia 21 września 2004 r. w sprawie wyceny nieruchomości $i$ sporzadzania operatu szacunkowego (Regulation of the Council of Ministers of 21 September 2004 on the issue of assessing real estate and preparing property valuation). Dz.U. $2004 \mathrm{nr} 207$ poz. 2109 z p. zm. (Journal of Laws of 2004 No. 207, item 2109 as ammended).

Ustawa z dnia 21 sierpnia 1997 r. o gospodarce nieruchomości (Act of 21 Augus 1997 on real estate management) t.j. Dz. U. z 2016 r. poz. 2147 z p. zm. (Journal of Laws of 2016 item 2147 as ammended). 